\title{
Reviews
}

\section{J. Velaza (ed.), Insularity, identity and epigraphy in the Roman world, Cambridge Scholars Publishing, 2017, ISBN: 978-1-4438-4704-9.}

Insularity, identity and epigraphy in the Roman world (Cambridge Scholars Publishing, 2017), edited by Javier Velaza, gathers a number of fourteen studies dealing with the classical Antiquity's perception of insularity and the practical consequences of being part of an "island culture". The book is the adapted result of an international congress held in Barcelona, in 2015

The first part, Islands and identities, consists of five articles which attempt at theorizing the notion of insularity in ancient context, often starting from case studies. The volume opens up with Atilio Mastino's and Raimondo Zucca's study, stressing on the individuality of Mediterranean islands. As they detail on the islands' particular features, historical evolution and unique reflection in ancient writings, the authors militate against a general key for interpreting insularity. Francesco Oliveira presents the also theoretical, but very circumscribed, view of Pliny the Elder on the Mediterranean islands. Pliny seems to regard islands as a point of junction, an in-between land which can be subjected to great natural disasters and unrest; his corpus of the known islands is self proclaimed selective, based on importance, visibility and/or symbolic criteria. The researcher concludes that, for the presented islands, the Naturalist's is certainly a reliable source of factual information. Nikoletta Manioti's research deals with the idea of island isolation in connection with/from the perspective of Ariadne's myth. Both Catullus and Ovid place Ariadne's abandonment on an island, echoing both the literary topos of a deserted land, isolated by the sea, and their contemporary realities of Roman exile. With a more practical, hands-on approach, Alejandro Díaz Fernández brings forth an analysis of the Roman Republican commanders of Sicily and Sardinia. The author demonstrates, starting from the epigraphic evidence of the two islands that, contrary to certain historiographic opinions associating proconsuls with provincial imperium during the Late Republic, praetorian governors were a rather common appointment. The last chapter of this part, written by Giulia Baratta, deals with monuments (not necessarily epigraphic this time) as main source of evidence as well. This time, the focus is the representation in a funerary context of ships transporting barrels - the cupae - and their relevance for the idea of visual cultural identity. The special popularity of the cupae in Sardinia and Lusitania is explained through their great involvement in Mediterranean, respectively Atlantic commerce and the identitary role taken on by this economic parameter.

The second section of the book is From the Atlantic to the Aegean and it opens up with Silvia Teixeira's overview on the epigraphy and archaeology of Tróia, part of peninsular modern day Portugal, but insular during Roman times. The site's economy, apparently highly supported by families and groups with great political influence and economical standing, revolved around the fish salting industry. The author mostly stresses upon the Mediterranean orientation which can be noticed in Tróia's society and economy, despite its physical location on the Atlantic shore. Geographically migrating towards the Aeolian islands, Philippe Tisseyre's research focuses on the trade

\section{Rada Varga}

Babeș-Bolyai University, Cluj-Napoca radavarga@gmail.com
INSULARITY, IDENTITY AND EPIGRAPHY IN THE ROMAN WORLD

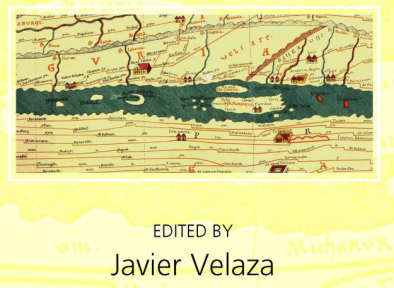

DOI: $10.14795 /$ j.v4i2.256

ISSN 2360 - 266X

ISSN-L 2360 - 266X 
routes between the given islands. Based on underwater archaeological discoveries - the concentration of shipwrecks in certain areas - he demonstrates how, due to the volcanic activity specific to the area, the maritime routs changed over time. Equally interesting, he proves that the ports which weren't nodal anymore weren't, as literary sources sometimes imply, abandoned, but continuously inhabited, even when becoming secondary economic actors. Dealing with a geographically well defined area as well, the next study discusses the promontory and islet of Licosa, situated by the Tyrrhenian Coast. Inhabited since prehistory, it seems that during classical Antiquity the ports along the Castellabate coastline were pivotal for millstone transportation - as several millstone quarries were archaeologically identified inland. Unlike the former chapters of this part, which mainly revolve around economical matters, Víctor González Galera investigates the theatrical traditions of Sicily. The author tries, more or less successfully, to see the change in theatrical language; while it is obvious that during the Republic Greek remained the main entertainment language, there are no inscriptions to allow us to draw clear-cut conclusions about what happened in this regard after Octavian's re-colonization of the island. Nonetheless, it is safe to assume that Latin gained a more prominent role as theatre language during the Imperial period. The chapter on the networks of wine trade in Roman Crete, signed by a large team (D. Martín-Arroyo, L. Prignano, I. Morer, G. Rull, M. García-Sáanchez, A. DíazGuilera, J. Remesal), tries to apply a speculative model to the selected historical realities and discover if theory fits the practice. Combining traditional approach with network analyses, the article draws conclusions on the people involved in trade, as well as on Crete's direct commercial connections. Processing large quantities of data, it became clear in which period and area Cretan wine was most popular: the Flavian era and respectively Pompeii.

After the general - and one could say, spatially generous - two first parts, the third and last one is $A$ case study: the Balearic islands, which gets to be a small monograph in itself. Initially, Josep Amengual i Batle discusses all the written evidence on the islands' names and image throughout antiquity. The ancient nomenclatures seem to be the roots for certain Byzantine and even modern toponyms (as Maiourikoi). This consequence is associated with an ideological consistency, perpetuating the cliché of the poor, talented slingers and rather savage inhabitants the Greek name of Gymnesian Islands comes from the fact that the locals allegedly wore no clothes. On a less theoretical level, Marc Mayer advances a few considerations on the waterborne routes including the Baleares. Administratively, the islands were a praefectura and later on, during Galba's reign, became part of the praefectura orae maritimae, which included the coasts of Hispania Citerior and Narbonensis. Strategically and economically important, the islands become "Romanized" (with all the generalisation implied by the term) quickly and display more of a typical Roman culture, than an insular one. In his research, the editor of the volume, Javier Velaza, investigates the phenomenon of insularity in epigraphy. The Balearic islands offer a model of epigraphic transfer, as a well defined group of funerary monuments, resembling as stylistic details and formulae, seem to belong to an immigrated group (possibly coming from the Italian Peninsula), who brought and conserved their own ways of expression. Small scale studies of such diffusion mechanisms can surely help us better grasp the large picture of European epigraphic habits. The last chapter belongs to Víctor Sabaté-Vidal who investigates a matter of true "insularity": the Iberian inscriptions from the Balearic Islands. The conclusions are relevant in context, as he states there are no hard evidences that an Iberian community lived on the Balearic Island. The only real Iberian inscription is a graffito, thus not necessarily local, and no other certain marks or epigraphs indicate the existance of a migrant community, as it was the case with the community presented in the previous study. This final part of the book, dedicated to the Balearic, is the most relevant one, as it offers a multifolded, complex and nuanced perspective on the respective islands.

Without being a milestone, the current book is a useful compendium on a subject not often tickled. The perspectives of the authors, as well as their focal interests, are quite different and most of the articles can represent valid starting points for deeper researches on the respective matters. Further so, arising the interest and tracing directions for the research of insular identity in Antiquity (and especially for the Roman world) is a step of great importance, as the matter is rather under-valued scholastically. From this point of view J. Velaza's work is a welcomed addition to any library and an interesting and often intriguing read. 